Vol. 6(12), pp. 398-405, December 2014

DOI: $10.5897 / J E N E 2014.0471$

Article Number: OD9C9AD49334

ISSN 2006-9847

Journal of Ecology and the Natural

Copyright (C) 2014

Environment

Author(s) retain the copyright of this article

http://www.academicjournals.org/JENE

\title{
Ecological study on the impact of mariculture fish cage site on the physico-chemical characteristics of Lagos Lagoon, South Western Nigeria
}

\author{
Olapoju, Oluwabukunola Ayokunmi ${ }^{\star}$ and Edokpayi, Clement Aghatise
}

Department of Marine Sciences, University of Lagos, Lagos State, Nigeria.

Received 3 September, 2014; Accepted 17 October, 2014

\begin{abstract}
A six months investigation on the environmental impact of fish cage culture on surface water and sediment of the Lagos lagoon were studied monthly from February 2011 to July 2011. Samples were collected from three stations, 1 (upstream of cage culture site), 2 (cage culture site) and 3 (downstream of cage culture site) between 07:00 and 11:00 h. During this period, the surface water ranged between $23.34 \pm 3.39-23.79 \pm 1.52^{\circ} \mathrm{C}$, depth ranged between $0.91-0.99 \mathrm{~m}$. The lowest $\mathrm{DO}$ value and highest biological oxygen demand (BOD) (mean $=4.43$ and $6.00 \mathrm{mg} / \mathrm{L}$ ) was recorded at station 2, respectively. These values may be due to the required oxygen used to break down fish wastes and excess feed pellets from the fish cage at this station. The analysis of variance test on parameters of water samples collected showed no significant difference $(p>0.05)$ among the three study stations while the analysis of variance test on the sediment samples collected showed significance difference $(p<0.05)$ in ammonium and total organic carbon among the study stations. There is a need for future development initiatives to focus on best management practices (BMPs) for low impact, ecologically sound and sustainable aquaculture.
\end{abstract}

Key words: Lagos lagoon, fish cage, water, sediment and Nigeria.

\section{INTRODUCTION}

Cultivation of marine fish in net cages is a growing industry with growing demand for aquatic products in both developing and developed countries which has led to this rapid change in the aquaculture sector in the past years. Fish consumption in developing countries is expected to increase by $57 \%$, from 62.7 million metric tonnes in 1997 to 98.6 million in 2020 (Delgado et al., 2003).

Cages are widely used in commercial aquaculture and the cage units come in different shapes and sizes modified to suit individual farmer's needs using materials such as PVC pipes, wood or steel. The cages were usually anchored to the bottoms of small, organically enriched streams, where the fishes are fed and grew on organic material and benthic organisms carried in the drift.

The rapid expansion in marine fish farming over the years have led to a growing concern on environmental impacts due to the discharge of waste products from the farms (Gowen et al., 1987). Fish farming was once

${ }^{\star}$ Corresponding author. E-mail: bukky.grace@gmail.com.

Author(s) agree that this article remain permanently open access under the terms of the Creative Commons Attribution License 4.0 International License 
considered an environmentally benign practice but is now viewed as a potential polluter of the marine environment due to organic enrichment of the seabed which can change the structure of benthic communities (Karakassis et al., 2000, 2002; Yucel-Gier et al., 2007). The deposition of organic material under the cages may cause changes in the composition of basic benthic communities in terms of abundance, dominance and species richness and the benthic loading alters sediment geochemistry, disrupts marine sessile communities and in some cases may affect the quality of the overlying water (Angel et al., 2000). It has also been observed that fish farm sediments are usually high in organic matter porous due to the supply of particulate organic wastes such as food and feacal pellets which may lead to sediment anoxia, algal blooms and reduction of biodiversity (Pearson and Black, 2001). The development of mariculture (fish farming) in Africa as a whole has experienced several setbacks due to lack of well documented information regarding possible negative environmental impacts due to mariculture and shortage of infrastructure and facilities, are among the drawbacks for the development of fish farming and other mariculture activities.

Weston (1990) studied the effects of organic enrichment on macrobenthic populations and observed a decrease in species richness and an increase in abundances of a few opportunistic species and overall reduction in biomass, yet an increase in the biomass of certain opportunists. Nigeria's vast water resources especially Lagos lagoon is mostly affected by environmental stress imposed by human population growth, urbanization and industrialization. The actual level of eutrophication in a farming area is mainly determined by sitespecific properties, such as water exchange and bottom topography.

With the increase in mariculture fish cage practices in Nigeria in other to improve food availability, lack of available work and knowledge on their impact on the environment necessitate the need to study the physico-chemical characteristics of water and sediment at the cage culture site of the Lagos Lagoon.

\section{MATERIALS AND METHODS}

\section{Description of study site}

Lagos lagoon is a multi-use re-source subject to fishing, recreational activities, dumping of solid wastes, non living resources (sand and coral) exploitation, effluent discharges and many other effects with an estimated area of $150.56 \mathrm{~km}^{2}$ (Figure 1). Figure 1 shows the sampling stations on Lagos Lagoon while the coordinates and approximate depth for each sampling stations are recorded in Table 1. It is generally shallow with a depth of between 0.3 and $3.2 \mathrm{~m}$ in most parts with the exception of some dredged parts, notably in the Lagos harbour where depth is $>10 \mathrm{~m}$. It is subject to semidiurnal tides and has a low tidal range $(<1.0 \mathrm{~m})$, its fetch is weak and the retention time is long. It opens into the gulf of Guinea through the Lagos harbor which is the only opening to the sea for the entire western lagoons of Nigeria.
The lagoon receives water from a large number of important rivers namely: Yewa, Ogun, Osun and Ona. It flows into the sea through the Lagos harbour which remains open all through the year and has a defined salinity gradient, linked with rainfall pattern extending inland westwards and eastwards (Hill and Webb, 1958). The salinity regime shows both a diurnal fluctuation due to tidal effect and much greater seasonal changes caused by influx of fresh water during the rainy periods.

The lagoon boarders the forest belt and receives water from a large number of important rivers. The salinity regime shows both a diurnal fluctuation due to tidal effect and much greater seasonal changes caused by influx of fresh water during the rainy periods.

\section{Description of the fish cage and types of fish cultured}

The mariculture fish cage was constructed using polyvinyl chloride (PVC) pipes as cage floatation material to ensure it stays afloat in water and a polyethylene was used for fabricating the cage ( this net is used because of its water repellent property) through the frame to a depth of $1.5 \mathrm{~m}$. A concrete slab was attached to anchor and stress the cage to give it a square shape structure and also prevent indiscriminate drifting of the net suspended.

The types of fish reared during the period of study at this site are Tilapia guineensis, Sarotherodon melanotheron and Clarias gariepinus. The culture time for the fishes was for a four month period and are fed with coppens fish feed twice daily and the average weight at time of harvest ranged between $0.6-1.2 \mathrm{~kg}$.

\section{Sample collection, preservation and analysis}

\section{Depth}

The depth was determined using a long pole with a measuring tape attached to determine the depth in metres. The pole is dipped down till it touches the bottom sediment. The pole is pulled up and the reading is recorded carefully to avoid all possible experimental errors.

\section{Water Temperature $\left({ }^{\circ} \mathrm{C}\right)$}

Water temperature was taken in situ at each sampling stations using dry bulb centigrade mercury in glass thermometer $\left(0-100^{\circ} \mathrm{C}\right)$. The thermometer is immersed just below the water surface for about 3-5 min to allow for acclimatization after which readings were recorded.

\section{Total suspended solids ( $\mathrm{mg} / \mathrm{l})$}

This was estimated by placing a pre-weighed filter on a holder and filtering $200 \mathrm{ml}$ of the water sample. The residue was dried to constant weight for one hour at $105^{\circ} \mathrm{C}$, cooled in desiccators and re-weighed. The drying was repeated until a constant weight was obtained. Total suspended solids, TSS (mg/l) was calculated as:

TSS $=$ Weight of residue $(\mathrm{mg}) /$ volume of sample filtered

\section{Total dissolved solids ( $\mathrm{mg} / \mathrm{ll})$}

Total dissolved solids were determined by filtering $200 \mathrm{ml}$ of water sample and then the filtered sample was transferred into a weighed crucible. The crucible was heated on a steam bath and then dried for an hour in an oven, cooled in a desiccator and weighed with the residue. 


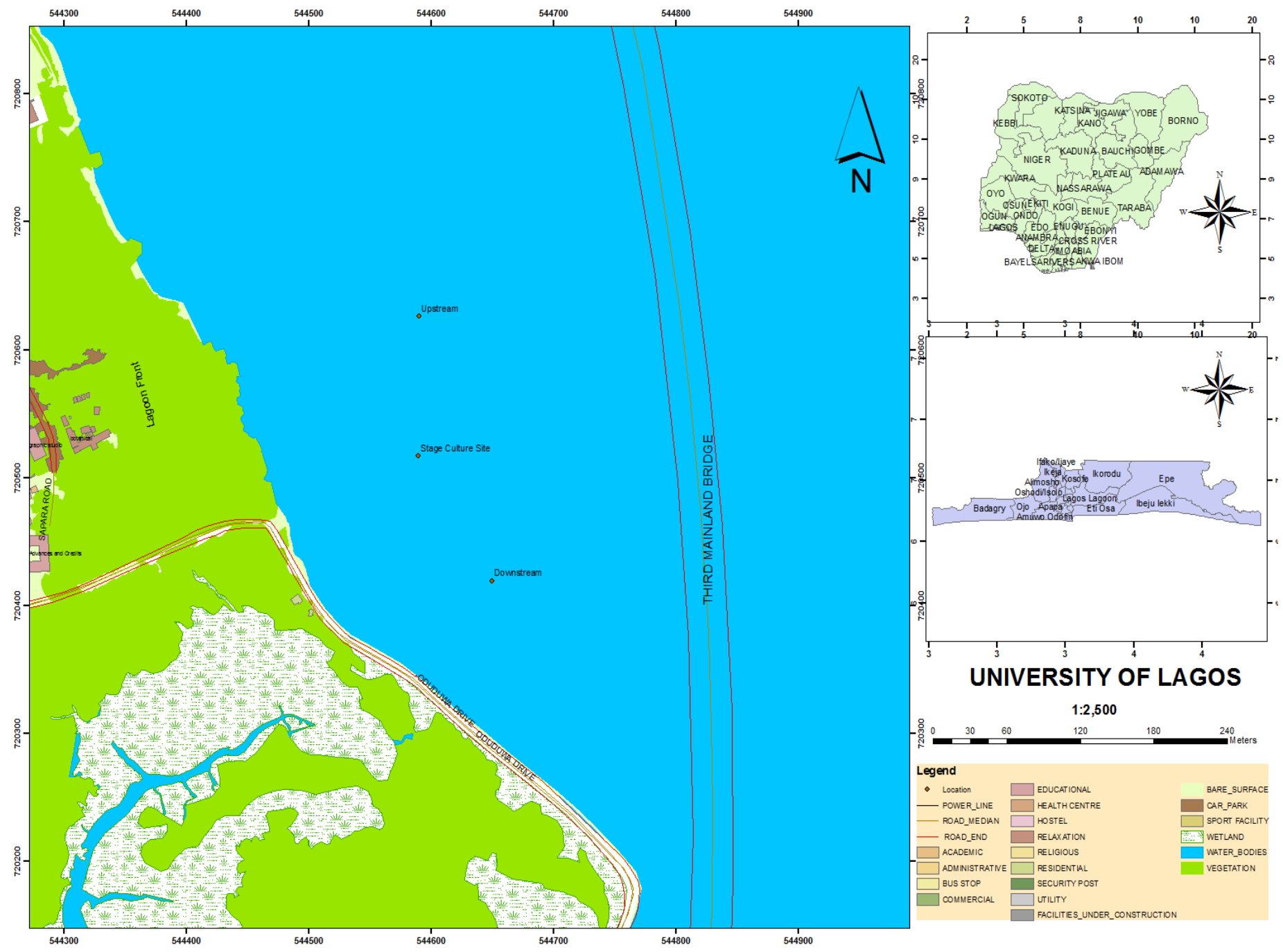

Figure 1. Map showing part of University of Lagos and mariculture fish cage with sampling sites.

Table 1. The study stations, their coordinates and approximate depth.

\begin{tabular}{llc}
\hline Stations & Coordinates & $\begin{array}{c}\text { Approximate } \\
\text { depth }(\mathbf{m})\end{array}$ \\
\hline 1 (upstream) & $\begin{array}{l}720625.585 \mathrm{~N} \\
544589.895 \mathrm{E}\end{array}$ & 1.03 \\
& $\begin{array}{l}720518.153 \mathrm{~N} \\
2 \text { (cage culture site) }\end{array}$ & 1.07 \\
& $544587.307 \mathrm{E}$ & \\
3 (downstream) & $720421.075 \mathrm{~N}$ & 1.13 \\
\hline
\end{tabular}

TDS = x-y (mg) / volume of sample $(I)$

Where: $X=$ weight of crucible, $Y=$ weight of crucible + residues after evaporation.

\section{Hydrogen ion concentration $(\mathrm{pH})$}

The hydrogen ion concentration of the water was determined using a handheld $\mathrm{pH}$ meter. The meter was first calibrated against buffer solutions of known $\mathrm{pH}$ values according to the manufacturer's specified procedure.

\section{Salinity (\%。)}

Salinity was determined by the use of EES salinity bridge meter (Model 13-13S). The probe was inserted into $500 \mathrm{ml}$ water sample container to estimate salinity levels from the display screen in parts per thousand $(\%)$.

\section{Dissolved oxygen}

The dissolved oxygen in water sample was determined using a portable hand held D.O. meter. The D.O. meter is first caliberated against standard D.O. calibration in line with the instrument manual before it was analysed for dissolve oxygen.

\section{Biological oxygen demand $\mathrm{BOD}_{5}^{20}(\mathrm{mg} / \mathrm{l})$}

Dissolved oxygen levels were first determined and then $250 \mathrm{ml}$ of water sample was measured into a glass reagent bottle $(A)$ and 
then treated with $10 \mathrm{ml}$ of $1.4 \mathrm{ml}$ tetraoxosulphate $(\mathrm{VI})$ acid. The other glass reagent bottle $(B)$ was also treated with $1.4 \mathrm{ml}$ of tetraoxosulphate $(\mathrm{VI})$ and potassium permanganate solution. The solution was incubated for five days at $20^{\circ} \mathrm{C}$. Solution in bottle $\mathrm{B}$ was then titrated with $0.0125 \mathrm{M}$ sodium thiosulphate using starch as indicator. The amount of sodium thiosulphate was recorded. The difference between this value and that of dissolved oxygen measured earlier was then recorded as the biological oxygen demand of the water.

$B O D=$ Initial DO - final DO

Where: $\mathrm{DO}=$ dissolved oxygen

\section{Chemical oxygen demand ( $\mathrm{mg} / \mathrm{l})$}

$10 \mathrm{ml}$ of potassium dichromate was added to $50 \mathrm{ml}$ of water sample. $1 \mathrm{~g}$ of mercury II sulphate and lead granules were added to the mixture. The mixture was heated in a reflux condenser for 10 min then left to cool. Two drops of ferrous indicator solution was added into the condensed solution titrated against ferrous ammonium sulphate II solution till the colour changed from blue green to red brown. Blank determination with $50 \mathrm{ml}$ distilled water was carried out and the difference between the two values gave the COD in $\mathrm{mg} / \mathrm{l}$.

\section{Heavy metals in water samples}

The metals in water sample were determined using Atomic Absorption Spectrophotometer (AAS) model SP - 500 with appropriate hollow cathode lamps. The AAS was standardized using calibration standard solutions of each metal in water sample and stock metal solutions were prepared according to the standard methods. A series of standard metal solutions were prepared by appropriate dilutions of the stock metal solutions. $20 \mathrm{ml}$ of $50 \%$ volume of concentrated nitric acid was added to $100 \mathrm{ml}$ of water sample and steamed for an hour. The resulting solution was aspirated into the AAS along with standards of various heavy metals (zinc, lead, iron, mercury, ammonium ion and copper).

\section{Nutrients in water samples}

Phosphate: Molybdenum reagent was prepared using:

i) $\left(\mathrm{NH}_{4}\right)_{6} \mathrm{MO}_{7} \mathrm{O}_{24} 1 \%$ in $\mathrm{H}_{2} \mathrm{SO}_{4}$ and

ii) Hydrazine sulphate $0.1 \%$

$10 \mathrm{ml}$ of $\left(\mathrm{NH}_{4}\right)_{6} \mathrm{MO}_{7} \mathrm{O}_{24} 1 \%$ in $\mathrm{H}_{2} \mathrm{SO}_{4}$ was mixed with $10 \mathrm{ml}$ of hydrazine sulphate $0.1 \%$ and diluted to $100 \mathrm{ml}$ after which it was left for two to four days. Standard phosphate was prepared using 1 $\mathrm{mg} / \mathrm{ml}$ of $4.39 \mathrm{~g} \mathrm{KH}_{2} \mathrm{PO}_{4}$ (dried at $110^{\circ} \mathrm{C}$ ) in distilled water with $1 \mathrm{ml}$ $\mathrm{CHCL}_{3}$ added before diluting with $1 \mathrm{~L}$ which equals $10 \mathrm{~g} \mathrm{PO}_{4}^{-}$. The sample $(20 \mathrm{ml})$ was acidified with hydrogen trioxonitrate $(\mathrm{V})$ acid and $25 \mathrm{ml}$ reagent added. The absorbance value was then read using a $780 \mathrm{~nm}$ filter. The phosphate content was then recorded in $\mathrm{mg} / \mathrm{l}$.

Nitrate (mg/l): Nitrate was determined gravimetrically. A mixture comprising $20 \mathrm{ml}$ of water sample and $1 \mathrm{ml}$ of freshly prepared 0.55 sodium salicilate solution was evaporated on the water bath. After cooling, $2 \mathrm{ml}$ of hydrogen tetraoxosulphate (IV) acid was added. After $10 \mathrm{~min}$, the solution was washed with $25 \mathrm{ml}$ distilled water into a calometry cylinder and $7 \mathrm{ml}$ alkaline reagent was added with distilled water up to $50 \mathrm{ml}$. The absorbance value was read from a photometer using $420 \mathrm{~nm}$ filter.
Sulphate ( $\mathrm{mg} / \mathrm{l})$ : This was determined using the turbidimetric method. The conditioning reagent was prepared to contain $30 \mathrm{ml}$ $\mathrm{HCl}, 300 \mathrm{ml}$ water, $100 \mathrm{ml} \mathrm{95 \%} \mathrm{ethanol} \mathrm{and} 75 \mathrm{~g} \mathrm{NaCl}$, and $50 \mathrm{ml}$ glycerol. 10 drops of conditioning reagent was added to $10 \mathrm{ml}$ of water sample and mixed. A pinch of barium chloride crystals was then added to the solution and allowed to stay for five minutes and then determined at $420 \mathrm{~nm}$ using a calorimeter previously calibrated with sulphate standard solution.

\section{Physico-chemical parameters of sediment samples}

Composite sediment samples were collected from each station for proper homogeneity and a portion is collected into a well labeled polythene bags for laboratory analysis. The polythene bags were labeled as: Station 1: Upstream station; Station 2: Fish cage area; Station 3: Downstream station.

\section{Total organic content (\%)}

A constant weight of sediment sample was put in crucibles for each sampling station and weighed up to $50 \mathrm{~g}$ then heated. The sample in each crucible was allowed to cool and re-weighed. The loss in weight after heating in the muffle furnace was calculated as loss on ignition using the formula:

$$
\text { Loss on ignition }=\frac{\text { Loss of weight on ignition }}{\text { Initial weight before ignition }} \times 100
$$

\section{Heavy metals ( $\mathrm{mg} / \mathrm{kg})$}

The heavy metals investigated are zinc $(\mathrm{Zn})$, lead $(\mathrm{Pb})$, copper $(\mathrm{Cu})$, mercury $(\mathrm{Hg})$, iron $(\mathrm{Fe})$ and ammonium $\left(\mathrm{NH}_{4}{ }^{+}\right)$using the $\mathrm{AA}$ 689 pye unicam 2003 Atomic Absorption Spectrophotometer (AAS). $10 \mathrm{~g}$ of dried sediment sample was digested with $20 \mathrm{ml}$ of nitric acid and was heated until the disappearance of the brown fumes and then allowed to cool after which distilled water was added up to the $50 \mathrm{ml}$ mark of a standard volumetric flask. The solution obtained was filtered and the filtrate was analyzed using the Atomic Absorption Spectrometer.

\section{Phosphates ( $\mathrm{mg} / \mathrm{kg})$}

The phosphate concentrations in the sediment were determined using the Olsen method. $2 \mathrm{~g}$ of each stations sediment sample was placed in a conical flask and $80 \mathrm{ml}$ of bicarbonate extract was added to digest the sediment and shaken for $30 \mathrm{~min}$. The resulting mixture was filtered and the filtrate measured using the AA 689 pye unicam 2003 Atomic Absorption Spectrophotometer.

\section{Nitrates $(\mathrm{mg} / \mathrm{kg})$}

The nitrate concentrations in the sediment were determined using $\mathrm{KCL}$ solution to digest the sediment. $2 \mathrm{~g}$ of the sediment sample was placed into an Erlenmeyer flask and $20 \mathrm{ml}$ of KCL solution was added. The mixture was shaken for $30 \mathrm{~min}$, after which it was filtered. The filtrate was measured using the Absorption Spectrophotometer.

\section{Sulphates $(\mathrm{mg} / \mathrm{kg})$}

The sulphate was determined using the HACH DR 2000 direct 
Table 2. Summary of physico-chemical surface water parameters of the study stations, Lagos Lagoon (February 2011 - July. 2011)

\begin{tabular}{|c|c|c|c|c|c|c|c|c|c|}
\hline \multirow{2}{*}{$\begin{array}{l}\text { Conditions } \\
\text { Parameters }\end{array}$} & \multicolumn{3}{|c|}{ Station 1} & \multicolumn{3}{|c|}{ Station 2} & \multicolumn{3}{|c|}{ Station 3} \\
\hline & Mean \pm SD & Min & Max & Mean \pm SD & Min & Max & Mean \pm SD & Min & Max \\
\hline TSS (mg/l) & $5.83 \pm 3.06$ & 2 & 10 & $6.83 \pm 3.19$ & 3 & 10 & $7.50 \pm 3.33$ & 2 & 11 \\
\hline $\mathrm{DO}(\mathrm{mg} / \mathrm{l})$ & $4.58 \pm 0.31$ & 4.1 & 4.9 & $4.43 \pm 0.38$ & 4 & 4.9 & $4.73 \pm 0.73$ & 4 & 5.9 \\
\hline BOD (mg/l) & $4.83 \pm 2.48$ & 3 & 8 & $6.00 \pm 2.37$ & 3 & 8 & $5.50 \pm 2.51$ & 2 & 8 \\
\hline COD (mg/l) & $11.33 \pm 6.80$ & 5 & 20 & $12.33 \pm 5.68$ & 5 & 18 & $12.67 \pm 6.71$ & 3 & 20 \\
\hline Salinity (\%o) & $14.83 \pm 11.60$ & 0 & 30 & $14.83 \pm 11.60$ & 0 & 30 & $15.67 \pm 12.21$ & 0 & 30 \\
\hline $\mathrm{pH}$ & $6.63 \pm 1.44$ & 4.8 & 8 & $6.52 \pm 1.34$ & 4.8 & 7.5 & $6.49 \pm 1.22$ & 4.92 & 7.5 \\
\hline Ammonium (mg/l) & $0.37 \pm 0.17$ & 0.17 & 0.61 & $0.38 \pm 0.14$ & 0.21 & 0.57 & $0.38 \pm 0.12$ & 0.17 & 0.16 \\
\hline Mercury (mg/l) & $0.006 \pm 0.004$ & 0 & 0.01 & $0.008 \pm 0.004$ & 0.01 & 0.01 & $0.008 \pm 0.002$ & 0 & 0.01 \\
\hline Zinc (mg/l) & $402.9 \pm 394.1$ & 76.54 & 916.2 & $401.8 \pm 398.0$ & 67.92 & 921 & $397.9 \pm 382.2$ & 75.99 & 897 \\
\hline Iron (mg/l) & $322.7 \pm 393.5$ & 107.1 & 1116.2 & $485.2 \pm 472.4$ & 119.5 & 1120 & $482.2 \pm 467.3$ & 119.8 & 11.05 \\
\hline Copper (mg/l) & $46.23 \pm 27.2$ & 15.29 & 76.54 & $46.49 \pm 27.25$ & 15.01 & 76.49 & $45.12 \pm 25.62$ & 15.2 & 76 \\
\hline Lead (mg/l) & $8.33 \pm 3.51$ & 5.36 & 13.12 & $8.45 \pm 3.29$ & 6.11 & 12.98 & $8.48 \pm 2.98$ & 6.4 & 12.8 \\
\hline Sodium (mg/l) & $2307.8 \pm 2162.2$ & 645.35 & 5381.4 & $2318.1 \pm 2162.8$ & 640.82 & 5390.6 & $2270.7 \pm 2086.9$ & 640.8 & 5391 \\
\hline Phosphates (mg/l) & $10.1 \pm 6.37$ & 2.44 & 18.01 & $9.67 \pm 6.31$ & 2.38 & 18 & $9.89 \pm 6.27$ & 2.4 & 17.8 \\
\hline Nitrates (mg/l) & $52.37 \pm 30.32$ & 16.25 & 84.09 & $55.49 \pm 34.25$ & 16.11 & 93.06 & $0.21 \pm 0.05$ & 16.23 & 98.7 \\
\hline Sulphates (mg/l) & $129.17 \pm 115.68$ & 18 & 282 & $133.5 \pm 120.07$ & 15 & 290 & $12.67 \pm 6.71$ & 18 & 275 \\
\hline Water temp. $\left({ }^{\circ} \mathrm{C}\right)$ & $23.64 \pm 1.51$ & 25 & 29 & $23.79 \pm 1.52$ & 25 & 29 & $23.34 \pm 3.39$ & 23 & 30 \\
\hline Air temp. $\left({ }^{\circ} \mathrm{C}\right)$ & $23.64 \pm 1.51$ & 25 & 29 & $26.79 \pm 1.49$ & 28 & 30 & $26.34 \pm 3.49$ & 27 & 30 \\
\hline Depth $(m)$ & $0.96 \pm 0.18$ & 0.79 & 1.27 & $0.99 \pm 0.07$ & 1.04 & 1.25 & $0.91 \pm 0.15$ & 0.79 & 1.25 \\
\hline
\end{tabular}

reading spectrophotometer, method 8051. After digestion of the sediment sample with distilled water, the HACH sulfa Ver 4, sulphate powder pillow reagent was used in $25 \mathrm{ml}$ of the solution against same solution containing no reagent as blank at a wavelength of $450 \mathrm{~nm}$.

\section{Statistical analysis}

All statistical procedures were adopted from Zar (1974). One-way ANOVA was carried out to compare the variations in parameters among stations during the period of study. When significant variations are detected, a Post-Hoc analyses using Duncan's new multiple range test were performed to determine the location of significant differences $(p<0.05$ was considered significant). Data analyses were carried out using SPSS software package for windows, version 15).

\section{RESULTS AND DISCUSSION}

The summary of the results for physical and chemical parameters of water and sediment samples at the 3 study station are presented in Tables 2 and 3 . The pattern of water and sediment characteristics is discussed based on the result observed. The surface water temperature at station 2 where the mariculture cage is situated (Table 2) is slightly higher than the value recorded at other stations. This corresponds with Edokpay and Nkwoji (2007) study. The discharges of organic wastes and inorganic wastes produced by coastal fishery aquaculture would directly bring some phenomena changes such as the increase of organic loads, for example, as BOD increases at the fish cage site, a decrease in dissolved oxygen (DO) was observed (Table 3). Cages used in aquaculture can reduce dissolved oxygen in water (Shu et al., 2002) and as recorded in this study, the low levels of dissolved oxygen recorded at the station 2 is evident that the uptake is due to the presence of the fishes being raised in the cage and fishes in this system may become stressed thereby resulting in their loss. This is a well reported trend for aquatic water bodies exposed to organic pollutants and it is also similar to past works reported for Lagos Lagoon (Akpata et al., 1993).

Salinity is a measure of the dissolved salts in the 
Table 3. Summary of physico-chemical sediment parameters of the study stations, Lagos Lagoon (February 2011 - July. 2011).

\begin{tabular}{|c|c|c|c|c|c|c|c|c|c|}
\hline \multirow{2}{*}{$\begin{array}{l}\text { Conditions } \\
\text { Parameters }\end{array}$} & \multicolumn{3}{|c|}{ Station 1} & \multicolumn{3}{|c|}{ Station 2} & \multicolumn{3}{|c|}{ Station 3} \\
\hline & Mean \pm SD & Min & Max & Mean \pm SD & Min & Max & Mean \pm SD & Min & Max \\
\hline TOM (\%) & $63.26 \pm 2.87$ & 59.08 & 65.3 & $63.72 \pm 2.92$ & 60.54 & 68.1 & $65.65 \pm 3.17$ & 58.9 & 65.8 \\
\hline TOC (\%) & $4.36 \pm 0.29$ & 4.1 & 4.81 & $4.41 \pm 0.22$ & 4.32 & 4.92 & $4.68 \pm 0.26$ & 3.84 & 4.44 \\
\hline Moisture & $29.57 \pm 3.84$ & 24.18 & 33.53 & $29.90 \pm 2.67$ & 27 & 34.82 & $27.88 \pm 2.26$ & 25.68 & 32.2 \\
\hline Phosphates & $0.04 \pm 0.005$ & 0.03 & 0.04 & $0.03 \pm 0.003$ & 0.03 & 0.05 & $0.04 \pm 0.01$ & 0.03 & 0.06 \\
\hline Nitrates & $0.22 \pm 0.01$ & 0.19 & 0.25 & $0.25 \pm 0.04$ & 0.21 & 0.29 & $0.26 \pm 0.01$ & 0.22 & 0.29 \\
\hline Sulphates & $10.33 \pm 2.33$ & 8 & 14 & $12.67 \pm 3.01$ & 9 & 16 & $11.67 \pm 3.01$ & 8 & 15 \\
\hline Ammonium (mg/kg) & $0.04 \pm 0.02$ & 0.04 & 0.08 & $0.07 \pm 0.02$ & 0.05 & 0.1 & $0.07 \pm 0.02$ & 0.06 & 0.1 \\
\hline $\operatorname{Mercury}(\mathrm{mg} / \mathrm{kg})$ & $0.004 \pm 0.002$ & 0 & 0.01 & $0.003 \pm 0.002$ & 0 & 0.01 & $0.005 \pm 0.002$ & 0 & 0.01 \\
\hline Zinc $(\mathrm{mg} / \mathrm{kg})$ & $0.36 \pm 0.07$ & 0.27 & 0.46 & $0.67 \pm 0.32$ & 0.32 & 1.21 & $0.59 \pm 0.32$ & 0.32 & 1.21 \\
\hline $\operatorname{Iron}(\mathrm{mg} / \mathrm{kg})$ & $353.3 \pm 140.2$ & 174.14 & 472.3 & $336.7 \pm 152.9$ & 140 & 460 & $344.3 \pm 147.6$ & 156 & 479 \\
\hline Copper(mg/kg) & $6.64 \pm 2.66$ & 3.58 & 9.2 & $7.96 \pm 3.68$ & 2.95 & 12.6 & $7.04 \pm 3.12$ & 2.95 & 12.6 \\
\hline Lead $(\mathrm{mg} / \mathrm{kg})$ & $1.86 \pm 1.17$ & 0.44 & 3.31 & $1.43 \pm 0.82$ & 0.44 & 3.31 & $1.95 \pm 1.36$ & 0.76 & 4.1 \\
\hline
\end{tabular}

mSTATION $1 \backsim$ STATION $2 \square$ STATION 3

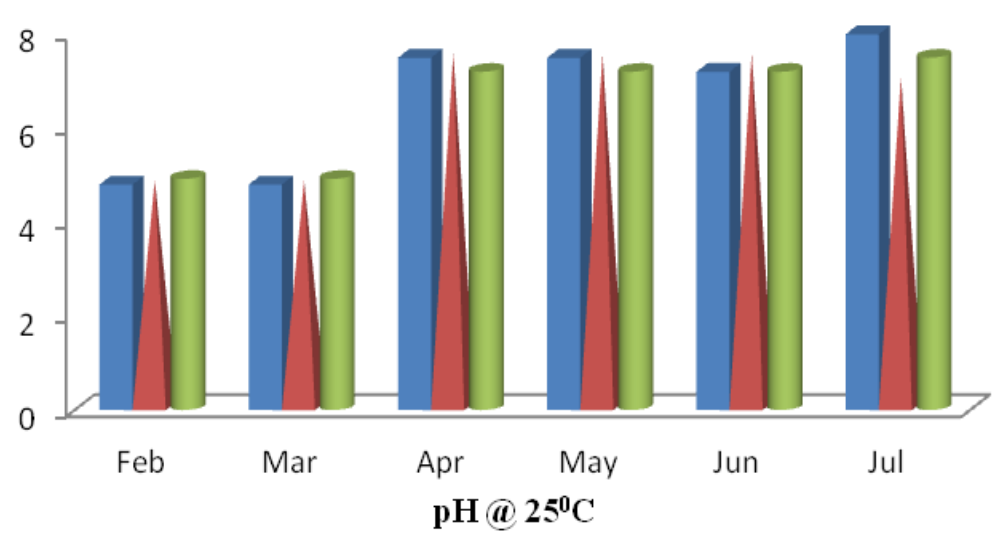

Figure 2. Monthly variation in $\mathrm{pH}$ at $25^{\circ} \mathrm{C}$ at the Lagos lagoon February July, 2011.

water. The results shows that salinity was higher in station 3 (Table 2) than the other two stations. However, the reported salinity range $(14.83-15.67 \%$ ) is within the brackish water range $(0.21-30 \%$ ) given by Laws (2000). The $\mathrm{pH}$ values recorded is one of the key environmental parameter that determines the survival, metabolism, physiology and growth of aquatic organisms and the values recorded during the period of study suggest an even distribution in surface water along the study stations (Figure 2).

The results observed in the surface water quality in terms of dissolved nutrients concentration in this study show a substantial increase in nitrate and sulphate concentration with an exception in phosphate concentration. In general, some $85 \%$ of phosphorus, 80 $88 \%$ of carbon and $52-95 \%$ of nitrogen input into the marine fish culture system as feed may be lost into the environment through feed wastage, fish excretion and faeces production.

Despite the high pollution loadings, results from various studies show that some $23 \%$ of carbon, $21 \%$ of nitrogen and $53 \%$ of phosphorus of feed input into the culture system is being accumulated in the bottom sediments and the significant impact is normally confined to the fish cage area having major impact on the sediment bottom (Yucel-Gier et al., 2007) However, in this study, the phosphates and nitrates concentration observed are low with a mean concentration of $0.03 \pm 0.003$ and $0.25 \pm 0.04$ respectively and the sulphates mean concentration is $12.67 \pm 3.01$. Furthermore, the maximum concentration of organic carbon is $4.92 \%$ recorded at stations 2 (Table 3 and Figure 4). When the organic matters accumulated in the bottom sediments are too much, the physicochemical index of the bottom will be changed (Figure 3 ) and the 


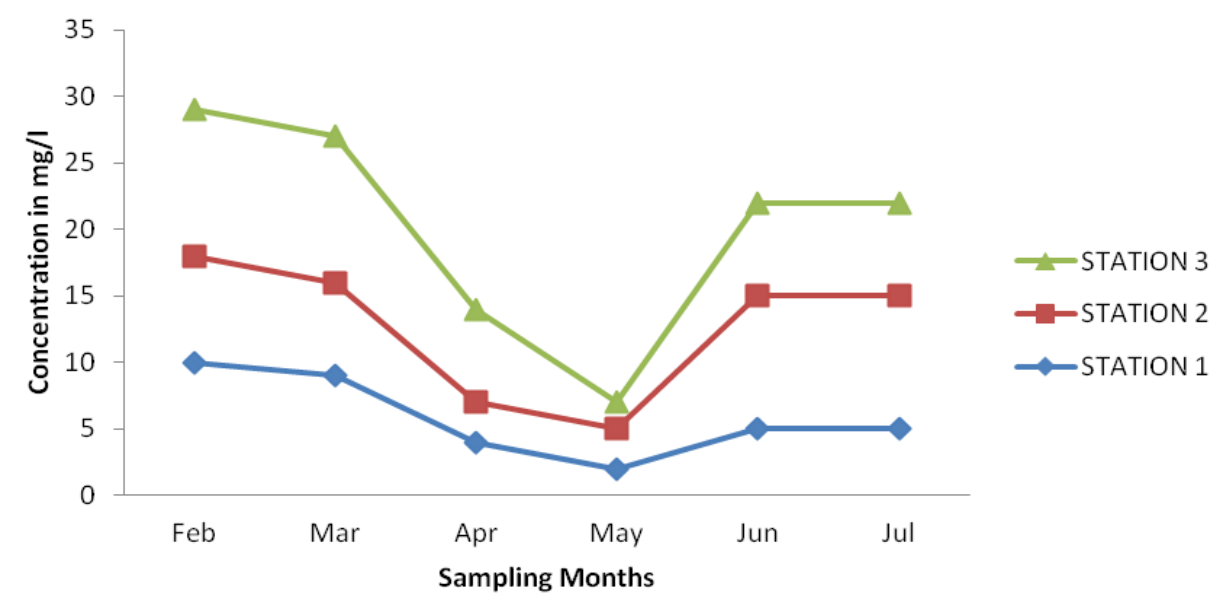

Figure 3. Temporal variation in total suspended solids at the Lagos lagoon (February - July, 2011).

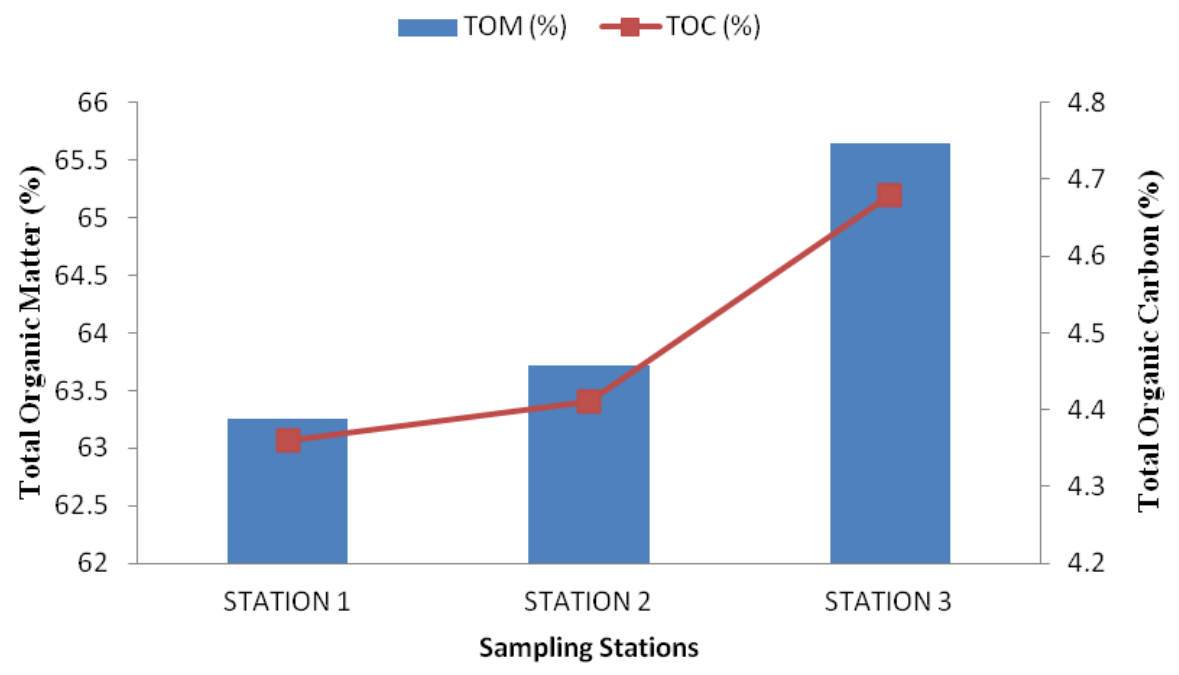

Figure 4. Mean of total organic matter, TOM (\%) and total organic carbon, TOC (\%) at the sampling stations (February - July, 2011).

decomposing function of microorganisms can results into bloom and the dissolved oxygen in the bottom is depleted as a result of numerous sulphates in the water (YucelGier et al., 2007). The results of statistical comparisons between concentrations of organic matter and organic carbon for all sampling stations at the fish cage culture site indicated no significant difference in the total organic matter ( $p>0.05$ ) which thus explains that there is relatively no change in the sediment characteristics of the Lagos lagoon during the period of study and a significant difference in the total organic carbon content (one-way ANOVA) $p<0.05$ indicates the resultant effect of residual feed deposition at the bottom of the cage facility in terms of organic carbon content and ammonium. Also, increase in sediment concentration of organic carbon observed during the period of study has been reported for sandy seabed.

As farming becomes more intensive and profit oriented, water resources will become threatened as a result of problems associated with poorly planned and inappropriate aquaculture developments in mariculture fish cage farming. As a general rule for cage culture, the minimum depth of water below the cage should be the same depth of the cage net, that is, there should be a minimum of $1 \mathrm{~m}$ of clear water below the bottom of the cage in order to keep it away from the mud and sediment (Ling, 1977) and as observed in this study, the depth profile of the study area where the fish cage is situated is considered shallow as a result, it may be the cause of the pollution problem which not only affect the environment but also the 
fishes reared in the cage. This has resulted in the need for future development initiatives to focus on best management practices (BMPs) for low impact, ecologically sound and sustainable aquaculture. So, as aquaculture is quickly developed because of the demands for aquatic products, some unreasonable phenomena such as the random discharge of aquaculture waste water and the abuse of medical medicines have seriously influenced the ecological environment negatively.

\section{Conflict of Interests}

The author(s) have not declared any conflict of interests.

\section{REFERENCES}

Akpata TVI, Oyenekan JA, Nwankwo DI (1993). Impacts of organic pollution on the bacterial, planktonic and benthic populations of Lagos lagoon, Nigeria. Int. J. Ecol. Environ. Sci. 19:73-82.

Angel DL, Verghese JJ, Saleh D, Zuber D, Lindell D, Symons A (2000). Impact of a net cage fish farm on the distribution of benthic foraminifera in the Northern Gulf of Eilay (Aqaba, Red Sea). J. Foraminiferal Res. 30(1):54-65.

Delgado CL, Wada N, Rosegrant MW, Meijer S, Ahmed M (2003). Fish to 2020: Supply and Demand in changing global markets. Washington D.C. International Food Policy Research Institute.

Edokpayi CA, Nkwoji SA (2007). Annual changes in the physicochemical and macrobenthic invertebrate characteristics of the Lagos lagoon sewage dump site at Iddo, Southern Nigeria. Ecol. Environ. Conserv. 13(1):13-18
Gowen RJ, Bradbury NB (1987). The ecological impact of salmonid farming in coastal waters: a review. Oceanogr. Mar. Biol. Annu. Rev. 25:563-575.

Hill HB, Webb JE (1958). The ecology of Lagos lagoon II: The topography and physical features of Lagos harbour and Lagos lagoon. Phil. Trans. R. Soc. Bull. 341:319-333.

Karakassis I, Tsapakis M, Hatziyanni E, Papadopoulou KN, Plaiti W (2000). Impact of cage farming of fish on the seabed in three Mediterranean coastal areas. ICES J. Mar. Sci. 57:1462-1471.

Karakassis I, Tsapakis M, Smith CJ, Rumohr H (2002). Fish farming impacts in the Mediterranean studied through sediment profiling imagery. Mar. Ecol. Prog. Ser. 227:125-133.

Laws EA (2000). Aquatic Pollution: An Introductory Text. ( $3^{\text {rd }}$ Ed.). John Wesley and Sons, Inc. New York. 639pp.

Ling SW (1977). Aquaculture in Southeast Asia. Seattle, Washington, University of Washington Press, $108 \mathrm{pp}$.

Pearson TH, Black KD (2001). The environmental impact of marine fish cage culture. In: Environmental Impacts of Aquaculture, Black, K.D. (ed.). Sheffield Academic Press, Sheffield, 1-31pp.

Shu Tingfei, Luo, Lin and Wen, Yanmao. (2002). Effects of Mariculture on Coastal Ecological Environment. Mar. Environ. Sci. 21(2):74 - 79.

Weston DP (1990). Quantitative examination of Macrobenthic community changes along an organic gradient. Mar. Ecol. Prog. Ser. 61:233-244.

Yucel-Gier G, Kucuksezgin F, Kocak F (2007). Effects of fish farming on nutrients and benthic community structure in the Eastern Aegean (Turkey). Aquac. Res. 38:256-267.

Zar JH (1974). Biostatistical Analysis. Prentice - Itali, Inc., New Jersey. 718 pp. 